\title{
ИСПИТИВАЊЕ ПОСТОЈАНОСТИ НА ТРЉАҢЕ ОТИСАКА ДОБИЈЕНИХ СУБЛИМАЦИОНОМ ШТАМПОМ
}

\section{EXAMINATION OF THE RESISTANCE TO RUBBING OF PRINTS OBTAINED BY SUBLIMATION PRINTING}

Јован Ћулибрк, Немања Кашиковић, Растко Милошевић Факултет техничких наука, Нови Сад

\section{Област - ГРАФИЧКО ИНЖЕЊЕРСТВО И ДИЗАЈН}

Кратак садржај - У оквиру рада представљена су истраживања из области дигиталне штампе. Штампање је врмено на три различите подлоге за штампу. Отисак је итампан на трансфер папир nомоћу "Ricoh SG 3110 DNw" сублимационог штампача, док се пренос отиска са трансфер папира на подлогу за итампу вриио помоћу термо пресе "Нobby Cut". Истраживана су заснована на скенирању узорака, мерењу спектрофотометријских вредности, трлању узорака, а затим анализи добијених резултата на основу којих је установљена отпорност отиска на трљање у зависности од подлоге. У раду је вршена и визуелна анализа узорака.

Ključne reči: Дигитална штампа, Сублимаџија, Трљање, Контрола квалитета, Анализа.

Abstract - The research has been presented in the field of digital printing. Printing was done on three different printing media. The color proof has been printed on transfer paper by Ricoh SG $3110 \mathrm{DNw}$ sublimation printer, while the transfer of the printed proof from transfer paper to the print media was done using a Hobby Cut thermal press. The research is based on sample scanning, measurement of spectrophotometric values, processing (rubbing) of samples, and finally the analysis of the obtained results which shows the resistance of the print to rubbing, depending on the substrate. Furthermore, the thesis also included a visual analysis of the samples.

Keywords: Digital printing, Sublimation printing, Rubbing, Quality control, Analysis.

\section{1. УВОД}

За разлику од штампарског поступка појам дигитална штампа, подразумева штампарску слику која до уласка у штампарску машину остане у дигиталној форми и тек у машини поново буде састављена у аналогну штампарску слику.

Није постигнута коначна сагласност о дефиницији дигиталне штампе и у публикацијама се различито многи штампарски поступци подразумевају као дигитализовани.

\section{НАПОМЕНА:}

Овај рад проистекао је из мастер рада чији ментор је био др. Немања Кашиковић, ван. проф.
Само ако се материјал одштампава елементима за наношење, дакле без штампарске форме односно са виртуелном имагинарном штампарском формом, онда се и овај процес одвија дигитално [1].

Сублимациона штампа је врста дигиталне штампе у којој боја (под дејством топлоте и притиска) прелази из чврстог у гасовито стање, те пријања на жељену површину која је намењена штампању [2]. За наведену технику штампе неопходан је сублимациони штампач са сублимационим бојама, сублимациони папир и сублимациона преса, те подлога за штампу на коју се отисак преноси.

Циљ овог рада јесте испитивање постојаности на трљање отисака добијених сублимационом штампом, при чему се посматра понашање боје на подлози за штампу пре и након сваке од серије трљања. Због ограничења броја страница у овом раду биће приказан експериментални део рада за један од три узорка, односно за микрофибер јастучнице.

\section{2. МЕТОД ИЗВОЪЕЊА ЕКСПЕРИМЕНТА}

Непосредно пре извођења експеримента штампана су "CMYK" и "RGB" мерна поља пуног тона, која су сублимацијом пренета на 3 различите подлоге за штампу: памучну мајицу, микрофибер јастучницу и полиестерску мајицу. Сублимациона штампа рађена је у фото студиу "Саnon M" у Новом Саду, при чему је отисак прво одштампан на трансфер папир помоћу "Ricoh SG 3110 DNw" сублимационог штампача, док ce пренос отиска са трансфер папира на подлогу за штампу вршио помоћу термо пресе "Hobby Cut". Након завршене штампе, мерене су почетне (референтне) вредности узорака на сваком од материјала пре трљања, помоћу спектрофотометра "HР 200". Вредности су бележене у “CIE LabCh" систему боја.

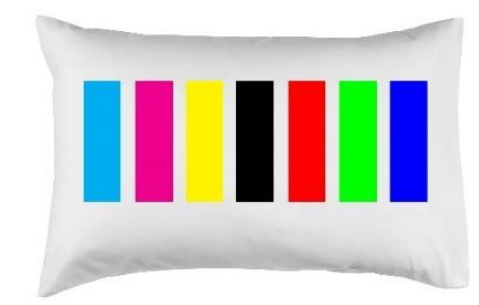

Сл. 1 - Микрофибер јастучница са мерним пољима 
Отисци су скенирани пре почетка трљања. Следило је трљање узорака помоћу “Теstex TF411” уређаја за трљање, приказаног на слици број 2.

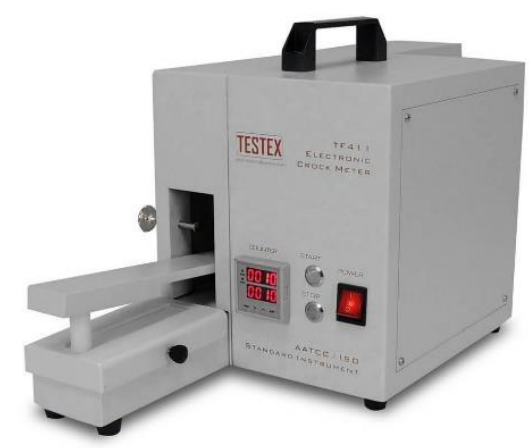

Сл. 2 - Уређај за трљање “Теstex TF411"

Трљање сваког узорка се вршило по 3 пута, тако да су се вредности боје мериле након завршене сваке серије трљања. Једна серија трљања обухватала је 250 понављања. Осим што су мерене вредности након сваке серије трљања, отисци су такође и скенирани помоћу "Canon Scan 5600F" уређаја, како би се омогућила и визуелна процена посматрача. Други део експеримента обухвата мерење разлике у боји узорака на сваком од материјала појединачно, при чему су посматране промене боје на датом материјалу пре и после сваке од серије трљања. Тако постоје следећи односи разлике у боји, дато по примеру микрофибер материјала: Разлика у боји пре и после 250 трљања, разлика у боји пре и после 500 трљања и разлика у боји пре и после 750 трљања. У даљем раду следе резултати и дискусија мерења за микрофибер материјал.

\section{3. РЕЗУЛТАТИ И ДИСКУСИЈА}

У наставку су представљене вредности "СМYК” и "RGB" мерних поља измерене у “CIE LabCh" систему боја, на микрофибер материјалу, односно разлика између боја пре трљања и након сваке од серија трљања.

Табеле од 1 до 7 приказују како се "CIE Lab" вредности одштампаних узорака мењају под утицајем трљања, док графици од 1 до 7 приказају те промене разлике у боји.

Табела 1 - Вредности за ичијан на микрофибер јастучници

\begin{tabular}{|c|c|c|c|c|}
\hline \multicolumn{5}{|c|}{ Цијан } \\
\hline \multicolumn{2}{|c|}{ пре трлана } & 250 трлана & 500 трльана & 750 трлана \\
\hline L & 68,94 & 68,64 & 68,67 & 68,44 \\
\hline a & $-11,19$ & $-11,00$ & $-10,90$ & $-10,47$ \\
\hline b & $-30,56$ & $-30,59$ & $-30,35$ & $-31,34$ \\
\hline C & 32,54 & 32,51 & 32,26 & 33,05 \\
\hline h & 249,89 & 250,21 & 250,24 & 251,53 \\
\hline
\end{tabular}

За вредности цијана на микрофибер материјалу, може се закључити да вредности светлине нису значајно одступале од референтних. Трљање цијан узорка је имало за резултат да боја постаје нешто црвенија и плавља. Засићеност (C) је након последњег трљања достигла већу вредност него што је то био случај пре почетка трљања.
Табела 2 - Вредности за магенту на микрофибер јастучниции

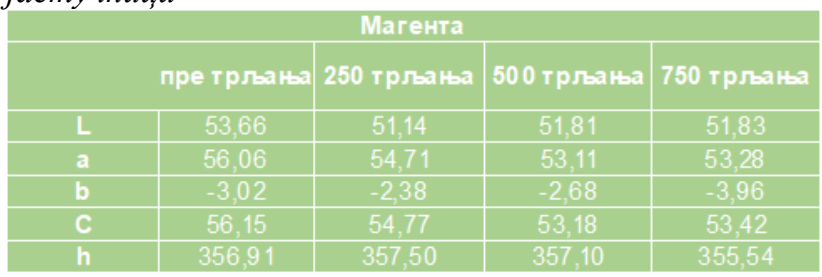

За вредности магенте на микрофибер материјалу, може се закључити да су вредности светлине (L) опале трљањем, те да је боја имала за резултат трљања промену нијанси ка зеленијим тоновима и нешто додатно плављим. Засићеност је постепено опадала трљањем, па је тако најнижа вредност овог параметра забележена након свих 750 трљања.

Табела 3 - Вредности за жуту на микрофибер јастучници

\begin{tabular}{|c|c|c|c|c|}
\multicolumn{5}{|c|}{ Жута } \\
\hline \multicolumn{2}{|c|}{ пре трлања } & 250 трлања & 500 трльња & 750 трлања \\
\hline L & 84,60 & 84,16 & 84,26 & 84,39 \\
\hline a & $-3,56$ & $-3,35$ & $-3,30$ & $-3,22$ \\
\hline b & 58,79 & 57,63 & 57,24 & 55,87 \\
\hline C & 58,90 & 57,72 & 57,34 & 55,96 \\
\hline h & 93,46 & 93,32 & 93,29 & 93,29 \\
\hline
\end{tabular}

За вредности жуте на микрофибер материјалу, може ce закључити да вредности светлине (L) нису бележиле значајнијих одступања. Боја је карактеристично другим измереним вредностима трљањем постајала плавља и смањивала интензитет засићености.

Табела 4 - Вредности за ирну на микрофибер јастучници

\begin{tabular}{|c|c|c|c|c|}
\hline \multicolumn{5}{|c|}{ Црна } \\
\hline & пре трлаңыа & 250 трлања & 500 трлања & 750 трлана \\
\hline L & 28,13 & 29,37 & 30,24 & 29,38 \\
\hline a & 4,54 & 3,69 & 3,70 & 4,58 \\
\hline b & $-6,03$ & $-6,72$ & $-6,57$ & $-9,46$ \\
\hline C & 7,56 & 7,67 & 7,54 & 10,52 \\
\hline $\mathrm{h}$ & 307,03 & 298,79 & 299,41 & 295,95 \\
\hline
\end{tabular}

За вредности црне на микрофибер материјалу, може се закључити да су вредности светлине расле трљањем, али је највиша вредност светлине забележена након 500 трљања. Боја је постајала трљањем све плавља, и поново је засићеност код црног узорка имала за резултат највећу вредност након последње серије трљања

Табела 5 - Вредности за ирвену на микрофибер материјалу

\begin{tabular}{|c|c|c|c|c|}
\hline \multicolumn{5}{|c|}{ Црвена } \\
\hline nре трлана & 250 трлана & 500 трлана & 750 трлана \\
\hline L & 52,04 & 53,23 & 53,70 & 54,55 \\
\hline a & 70,73 & 68,03 & 66,92 & 65,56 \\
\hline b & 11,71 & 10,51 & 10,18 & 8,07 \\
\hline C & 71,69 & 68,84 & 67,69 & 66,06 \\
\hline h & 9,39 & 8,77 & 8,63 & 31,14 \\
\hline
\end{tabular}

За вредности црвене на микрофибер материјалу, може се закључити да су вредности светлине (L) постепено расле након сваке серије трљања, као и то да је боја бележила промену нијансе ка зеленијим и плављим тоновима. Засићеност је очекивано опадала сваком 
серијом трљања и најнижу вредност достигла управо након последње серије трљања.

Табела 6 - Вредности за зелену на микрофибер материјалу

\begin{tabular}{|c|c|c|c|c|}
\hline \multicolumn{5}{|c|}{ Зелена } \\
\hline & пре трлана & 250 трльања & 500 трльања & 750 трльана \\
\hline L & 67,34 & 67,42 & 67,28 & 67,27 \\
\hline a & $-21,53$ & $-20,72$ & $-20,78$ & $-20,51$ \\
\hline b & 31,45 & 29,75 & 29,59 & 27,09 \\
\hline C & 38,12 & 36,25 & 36,16 & 33,98 \\
\hline h & 124,40 & 124,86 & 125,08 & 127,13 \\
\hline
\end{tabular}

За вредности зелене на микрофибер материјалу, може ce закључити да вредности светлине (L) нису забележиле значајна одступања, боја је благо тежила ка црвенијим и плављим нијансама, док је засићеност очекивано, опадала сваком серијом трљања и најнижу измерену вредност забележила након последње серије трљања.

Табела 7 - Вредности за плаву на микрофибер материјалу

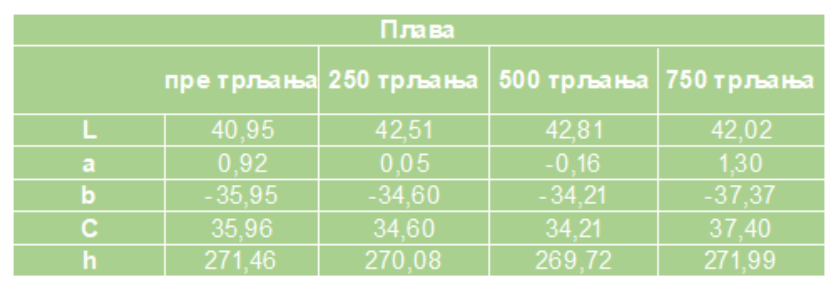

За вредности плаве на микрофибер материјалу, може се закључити да су вредности светлине (L) расле сваким трљањем, али је највећа вредност забележена након 500 трљања, као што је било у неким од претходних примера. Интересантно код плавог узорка јесте промена боје по “а" параметру, где се види да је боја мењала нијансе ка зеленој, потом након 3. серије трљања нагло променила правац ка црвенијој нијанси. Пратећи параметар “b” трљање је довело до тога да боја постане нешто плавља. Вредности засићености (C) су падале током прве две серије трљања, а затим нагло забележиле раст и имале већу вредност од референтне након последњих 250 трљања.

Како би се промене у боји јасније уочиле, следе објашњења уз графике од 1 до 7 за сваку од боја на микрофибер материјалу.

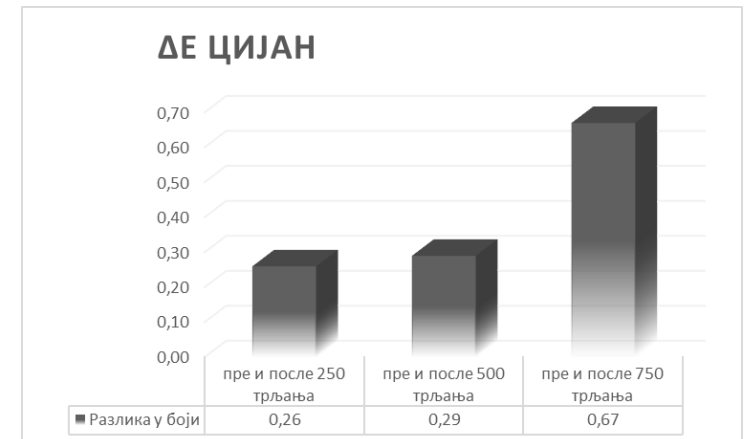

График 1 - Разлика у боји за цијан на микрофибер материјалу

Мерењем разлике у боји за узорак цијана на микрофибер јастучници може се закључити да је разлика у боји постепено расла након сваке серије трљања и да је највећа разлика детектована пре и после 750 трљања, међутим, недовољно да би и увежбано око могло да примети.

\section{$\triangle E$ MAГEHTA}

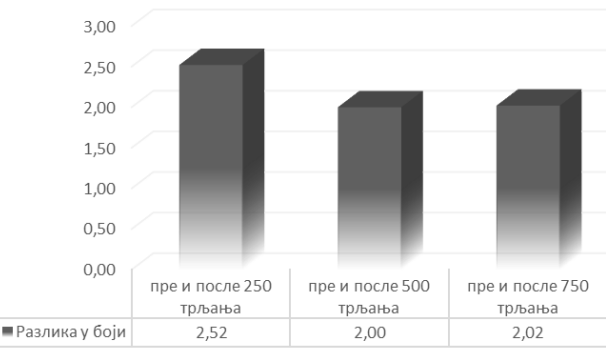

График 2 - Разлика у боји за магенту на микрофибер материјалу

Мерењем разлике у боји за узорак магенте на микрофибер јастучници највећа разлика у боји запажена је након прве серије трљања, са оценом да је разлика видљива и неувежбаном оку. Следеће две серије трљања бележиле су ниже вредности, али исту оцену, те би и у том случају неискусно око могло да примети разлику.

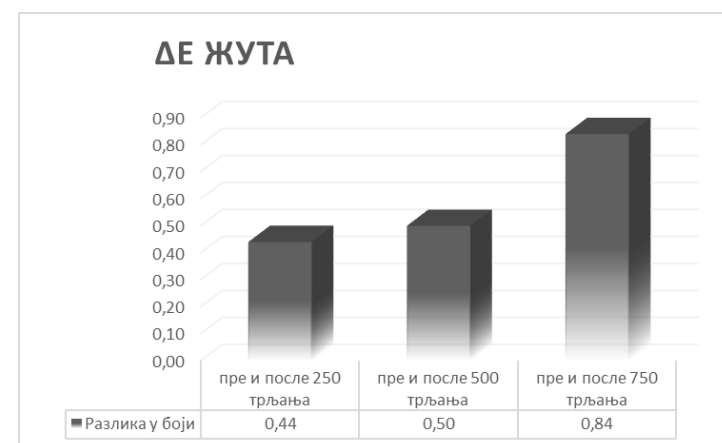

График 3 - Разлика у боји за жуту на микрофибер материјалу

Мерењем разлике у боји за узорак жуте боје на микрофибер јастучници може се закључити да је разлика у боји постепено расла након сваке серије трљања и да је највећа разлика детектована пре и после 750 трљања, међутим, недовољно да би и увежбано око могло да примети.

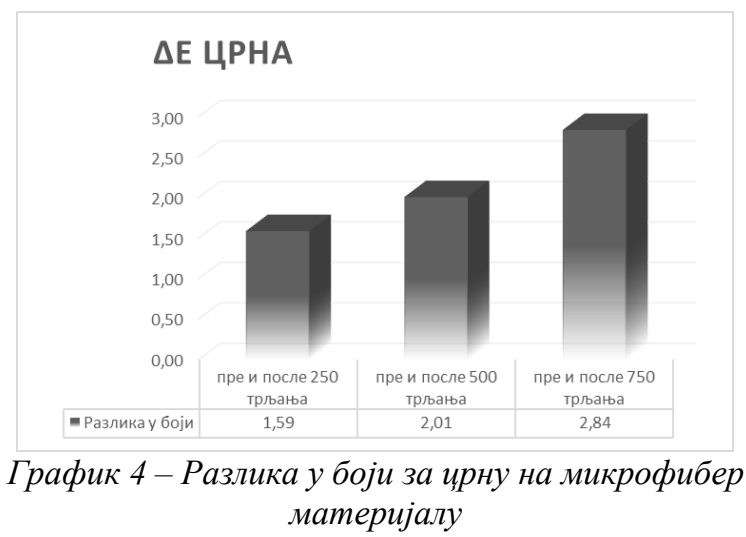

Мерењем разлике у боји за узорак црне боје на микрофибер јастучници може се закључити да је разлика у боји постепено расла након сваке серије трљања и да је највећа разлика детектована пре и после 750 трљања, па је тако закључак да у овом случају и неискусно око може да примети разлику. 


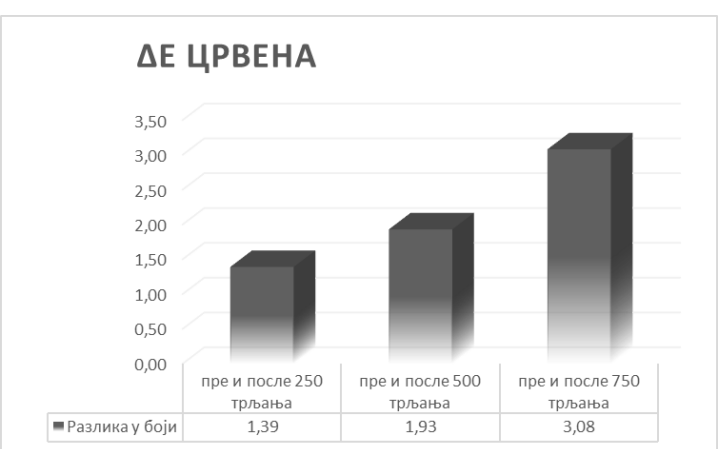

График 5 - Разлика у боји за ирвену на микрофибер материјалу

Мерењем разлике у боји за узорак црвене боје на микрофибер јастучници може се закључити да је разлика у боји постепено расла након сваке серије трљања и да је највећа разлика детектована такође пре и после 750 трљања. Вредности са прва два графика указују на то да разлику у боји може приметити само увежбано око, док се након последњих 250 трљања разлика може приметити и од стране неувежбаног ока

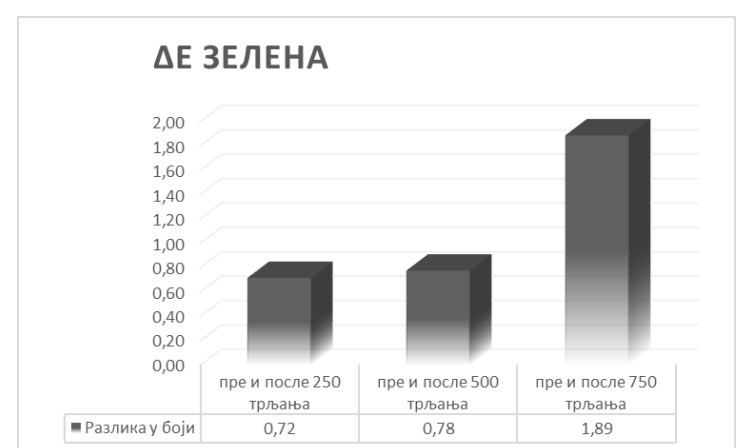

График 6 - Разлика у боји за зелену на микрофибер материјалу

Мерењем разлике у боји за узорак зелене боје на микрофибер јастучници може се закључити да је разлика у боји постепено расла након сваке серије трљања, с тим да у прва два случаја разлика није била видљива. Након последње серије трљања долази до наглије промене вредности, што је и највећа разлика у боји и видљива је само увежбаном оку.

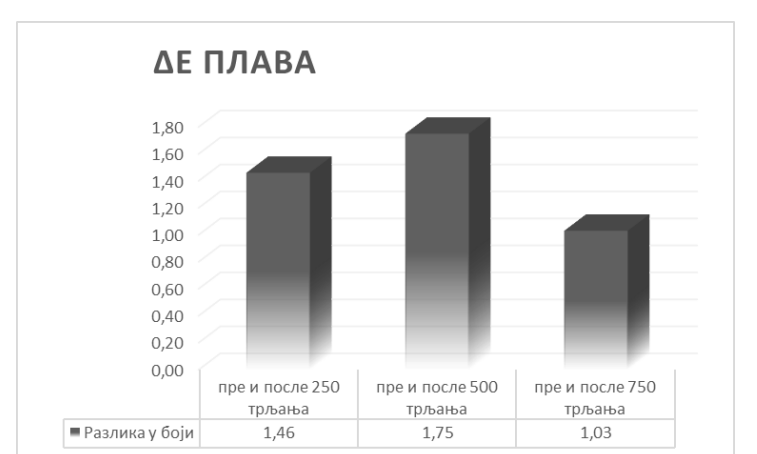

График 7 - Разлика у боји за плаву на микрофибер материјалу
Мерењем разлике у боји за узорак зелене боје на микрофибер јастучници може се закључити да је највећа разлика у боји забележена пре и после 500 трљања што значи да је приметно само увежбаном оку. Интересантан податак јесте да однос пре и после 250 трљања има већу измерену разлику у боји него однос пре и након свих 750 трљања.

\section{4. ЗАКЉУЧАК}

Развојем технологија расту и технике и могућности штампе, али је у сваком тренутку важно вршити контролу отисака. У овом раду вршена је контрола отисака за памучни, полиестерски и микрофибер материјал. Праћено је понашање боје и материјала излагањем физичким силама трљања. Сублимација се као штампа показала поузданом за добијање постојаног отиска, чак и када се пренесени отисци изложе физичким силама трења.

Ни у једном случају није забележен нестанак боје са подлоге, што се може оправдати употребом термалне пресе која под високом температуром уз притисак и одређено време запече отисак на материјал.

Закључак рада јесте да се контролом постиже не само сигурност и квалитет током рада, већ и податак више - богатимо се информацијама о стању, квалитету, понашању боје и још пуно више информација.

Веома је важно пратити квалитете отисака, материјала и њихову међусобну интеракцију. Скуп ових информација даје нам гарант да познајемо наш рад и да током штампе неће бити ситуација које не можемо да решимо.

\section{5. ЛИТЕРАТУРА}

[1] Grid (2018), Nastavni materijal za studente iz digitalne štampe [Online] Доступно на: http://www.grid.uns.ac.rs/predmet2.html?predmet $=92$

[2] Znacenje reci (2018), Sublimacija [Online] Доступно на: https://www.znacenjereci.com/sta-je-sublimacija/

[3] Novaković D., Karlović I., Pavlović Ž., Pešterac Č. (2009), Reprodukciona tehnika - priručnik za vežbe, FTN izdavaštvo, Novi Sad.

\section{Адреса за контакт:}

MSc Јован Ћулибрк, culibrk.j@gmail.com

Др Немања Кашиковић, knemanja@uns.ac.rs

MSc Растко Милошевић, rastko.m@uns.ac.rs 